\title{
Fuster's Conception of Literature as a Social Practice
}

\author{
Vicent Salvador* (Universitat de Jaume I, València) \\ vicent.salvador@uji.es_http://orcid.org/0000-0001-8927-6836
}

\begin{abstract}
Joan Fuster's essays constitute the observatory from which he examined the world, human beings and the life of society. In this observatory-cum-laboratory, Fuster used linguistics, culture, aesthetics, the sociopolitical context and history to construct his theory of social reality. He often focussed on literary phenomena - authors, genres, movements, styles and publishing processes - in the context of the vast process of social praxis, an ambit in which no element can be innocently isolated from any other, from the whole in which all things are interrelated. Fuster's conception of literature thus adopts a perspective of complexity in which the idea of writers being socially engaged, of great influence at the time, is filtered by means of critical examination. This examination includes highly diverse and often contradictory factors that the author tries to balance against each other with an intellectual honesty that turns paradoxes into the driving force behind his writing.
\end{abstract}

Keywords: Joan Fuster, intellectual, engagement, literary genres, essay

\section{Between politics and literature}

For the Valencian writer Joan Fuster (1922-1992), 1962 was a year of splendid literary output, a genuine annus mirabilis from the publishing point of view. In fact, he was so successful that he was relieved by Alfons Cucó of his traditional responsibility of producing the annual report on Valencian publications in 1962 for the almanac "Cap d'any" of the Majorcan journal Raixa. It would not have seemed proper for the author of four books published that year - Qüestió de noms (A Question of Names), Poetes, moriscos i capellans, (Poets, Moriscos and Priests), Nosaltres els valencians (We, the Valencians) and El País Valenciano (The Valencian Country) to review his own extensive production, which eclipsed - at least in terms of quantity - what had been published by his fellow Valencians. Fuster was a writer, critic and cultural organiser, and he often had to take on a multiplicity of roles in the modest world of publishing of the time, but, in the provincial environment of the Valencian Country, reviewing his own work would have been regarded as hogging the limelight, particularly considering that We, the Valencians, the first book to be published by one of the flagship publishing companies of Catalan culture - Edicions 62 - put forward some forceful and controversial ideas on Valencian identity.

What is more, one of Fuster's books that were published that year, The Valencian Country, had unleashed the fury of the most reactionary sectors of Valencian society, who interpreted his writing on certain issues as a lack of respect for the essence of local tradition. In the background, there was also the jealousy of an influential local journalist who had been anxious to make a contribution to the series "Guías de España", where he would have been published alongside such authors as Josep Pla, Pío Baroja, Dionisio Ridruejo and José Maria Pemán [1]

*Vicent Salvador is currently Professor at the Universitat de Jaume I, Castelló de la Plana (Department of Philology and European Cultures), Valencia. His main research areas include Discourse analysis, Pragma-stylistics and Contemporary Catalan Literature. 
(Pérez i Grau 2016). The affinity that Josep Pla felt for Fuster, the fact that he perceived him to be a racé writer, seems to have been fundamental in the decision taken by the publishers, Destino. This decision was taken in 1958 and had been in favour of the young Fuster, even though he was at some considerable remove from the Spanish conservatism of the time and was in constant and active touch with the journals of the Catalan exiles on the American continent (for example, Pont Blau and La Nostra Revista). Also in 1962, Fuster wrote a letter to his friend Vicent Ventura, who had fled to Paris after taking part in a meeting against the Franco regime (the socalled "Munich Conspiracy"). After stressing that internal cultural resistance was just as important as the resistance offered by the exiles, he provided a self-definition that highlighted his qualities as a writer rather than his qualities as a politician:

As far as I am concerned, despite my wholly intellectual appearance, I also suffer from the Celtiberian shortcoming of wanting to put the country to rights. Of this you are well aware. And I'm beginning to get a little fed up that readers think of me more as a "politician" than as a "man of letters". This does have an effect on my pride. [...] I have absolutely no desire to pretend to be what I am not, and the fact that I have no "followers" and am not a "leader" but merely what is often referred to as a "moral authority" means that I am more comfortable with how I do things. And I cannot complain about how effective it is. (Fuster 2003: 73)

A few lines afterwards, he uses the expression "raising awareness" to sum up his ultimate aim as an agent of the historical change of his society. In these few lines from his correspondence, Fuster effectively describes his characteristics as a writer - or rather, man of letters, which adds a touch of vanity - who carefully observes life in the society around him and who restricts his function to that of an ethical authority who raises awareness. This is the role that he adopts. No more and no less. By vanity, he who had often harshly criticised the narcissistic fickleness of poets undoubtedly means his ambition to become a leading figure in the field of culture he had chosen as his own (that is to say, literature). He also imposes on himself the responsibility of making an effective contribution to ethical and civic awareness, but without being at the forefront of political activity.

I shall focus on the role in his conception of literary practice that combines the intrinsic values of literature as an autonomous domain and ethical engagement with historical social change. This double perspective shapes Fuster's outlook in terms of how he views his own work and how he conceives literature in general. Of course, Fuster makes no systematic analysis of literature in any of the numerous pages he wrote because he is not an academic theoretician. As Martí Monterde (2002: 77) says, he resisted "stagnating methodologically". And it should be said that the dominant genre of his writings, the essay, is hardly the most conducive to the methodological stagnation of thought. He did not even produce any programmatic reflections as Sartre did in his well-known attempt to define literature. Having said this, literary theorisation in the broad and generous sense of the term, is by no means absent from his work: it flows hither and thither, in minor papers, in prologues, in aphorisms and in unexpected digressions even though the dissemination of his ideas on such a vast and complex subject makes it difficult to interpret as a whole.

Nevertheless, there is one factor that may encourage an analyst to delve into Fuster's theory of literature: his fidelity to his own thinking, the originality of his ideas. His approach to literary issues clearly evolves over time: it becomes increasingly informed; it develops by comparison with different or dissenting opinions, just as thinking that aspires to be critical needs to. However, his flow of ideas never gives way to successive academic fashions and neither does it undergo the sudden changes of direction that are so common in the careers of many thinkers. On the contrary, he is steadfastly loyal to his own principles and he sifts all conceptual and methodological novelties through his privileged mind, a thinking machine that works like clockwork.

The main problem involved in the task of summarising Fuster's ideas is his method of constructing discourse and thought, reflected in his choice of the essay and opinion journalism as a means of expression: he combines a continual re-examination of ideas with a passion for the brilliant turn of phrase designed to seduce the reader. The axiom that writers have the inescapable obligation of being read often influences how they present theories, so they resort to risky metaphors, iconoclastic remarks or surprising definitions with an aphoristic aftertaste. Here are some examples: poetry is an "erethism of words"; critical readers - real readers - "chew ideas over"; 
Goethe is "like an inhospitable mountain, like a tempestuous sea""; Flaubert was "an obsessive, cold and constipated novelist"; two essays by Camus, which he had translated into Catalan himself, are "two miserably naïve papers"; literature includes "the never-ending chewing gum of metaphysics"; and "a psychologist is little more than an unskilled novelist".

On these occasions, Fuster seems to succumb to the temptation of expressive brilliance and prefers an immediate dramatic impact to the precision of conceptual nuances. After all, this is the price that the essayist has to pay for a flowing discourse, which is contaminated by the journalistic style and the sententiousness of aphorisms. But it should also be said that, at the same time, it is an epistemological strategy that renounces academic abstractions and he opts to literarily construct his ideas on literature. Whatever the case may be, Fuster's prose is excessive and fun. He constantly provokes and fascinates the reader, and this is partly why those who study his work feel the unrestrainable need to quote him literally instead of rephrasing what he says in other words.

\section{Engagement and scepticism}

A lot has been said - as far as I am concerned, too much and too opinionated - on the apparent contradiction between Fuster's scepticism and his undeniable sense of ethical and civic engagement, about which he was to write on several occasions. This was a crucial issue for the European intelligentsia of the period in which he was constructing his thought, particularly on the basis of Sartre. Despite his engagement, Fuster also had a sceptical side to him, which he expressed quite explicitly (he was constantly saying that, unlike a credulous communicant, he was "nobody's fool"), and his prose made repeated use of such resources as irony, paradox and the desacralisation of solemn constructions. One of the most essential features of his use of language and his "philosophy" of language is his firm decision to practise "lexicographical hygiene" in an attempt to "remove metaphysics" from discourse, in the same way as his much-admired Russell used to do. Or, in other words, he adopted a critical attitude to the ideologies that lexis carried with it - made invisible by the effect of inveterate conventions - as a tribute to the ups and downs of cultural and social history within which it had been created. Indeed, for him, possessives are insidious, adjectives conceal a wealth of subjective appreciation and the word "I", as an illusion of unitary identity, is little more than an indispensable superstition. Deep down, the humanist ideal involves an intellectual suspicion, a resistance to inert knowledge and, therefore, to routines inherited through language, as was stated by Edward W. Said (2006: 65): "Humanism is, to some extent, a resistance to idées reçues, and it offers opposition to every kind of cliché and unthinking language." This critical, sceptical humanism, reticent about mental inertia, is undoubtedly one of the fundamental pillars of the attitude of an intellectual.

So, for some of the scholars who have studied Fuster, scepticism and engagement are an almost insoluble antinomy. Personally, I feel that it is straightforward to solve if the two extremes are placed on different planes: scepticism needs to be understood as an epistemological method, and engagement as a way of life. From this point of view, scepticism is that route to knowledge which invokes prudence, caution and "methodological suspicion" - an intensification of Cartesian doubt - to cope with the routines of thought that the dominant ideologies use to imperceptibly ensnare and tame us. On the other hand, (civil, social and national) ethical engagement is an attitude that informs personal behaviour and guides the writer's struggle in the context of the surrounding society. After all, the ultimate objective of the two principles lies in the strategy of standing up to the manipulations of power, of the powers that detract from the humanist ideal of leading a full life in the framework of a more just society. Scepticism cannot be mistaken for cynicism or apathy, because deep down, it is merely a mechanism for intelligently selecting the most appropriate procedures. When Fuster says that you should have few convictions (only those that are absolutely necessary), this is what he is referring to.

Nevertheless, Fuster's engagement is much broader than the engagement proclaimed by Sartre in the post-World War II period: we could say that it is a rope made with more strands. In fact, Fuster's engagement is with his language, even though practical necessities often required him to write in Spanish, a paradox that was not a part 
of Sartre's social engagement, for instance. The French language did not need anyone to fight for it, but writing in Catalan, being engaged with Catalan, did require extra energy because it was like trying to hold back the tide. Of course, we could also say something similar about his engagement with Catalan nationalism, which focussed in particular on the historical, social and cultural peculiarities of the Valencian Country. Much of what Fuster wrote in We, the Valencians; The Valencian Country; and Now or Never, as well as in his protest pamphlets, aimed to clear up the conflicts about Catalan and, above all, Valencian identity. As Neus Panalba (2015: 271) points out, Fuster walks the thin dividing line between universality and singularity: "His most extraordinary achievement is that he is at once an intellectual from a small town in the periphery, far removed from the epicentres of power and the cultural capital, but he never succumbs to provincialism or nationalistic myopia." Being so far from Paris and even Barcelona - at least in terms of geography and the media - it is not easy to be an influential intellectual. He did not even take advantage of Madrid as a communicative platform to denounce Spanish nationalism. This particular intellectual was - and this is how he presented himself - a "small-town guy", more specifically from Sueca, which is where he lived all his life. He took such pride in it that he constructed an ethos of a thinker isolated from the noise generated by the city and the centres of cultural power. One of the images that he constructed and projected throughout his life was "that of the solitary intellectual, shut away in his rural refuge, who uses his writing and talks to provide teachings of considerable humanistic value" (Nicolàs 2002: 145).

Likewise, his nationalism was, as he said himself, reactive, the ethical obligation of a Catalan who aspired to universality but who felt he had to stand up to a powerful foreign nationalism. But his most significant challenge was to dedicate much of his work to searching for local or regional Valencian roots, a very specific problem that was inscribed in the general context of Catalan language and culture: a good example is his study of the peculiarities of the historical process of Castilianising the Valencian Country. And above all, he always took the epistemological decision of dealing with "local" problems from a panoptic and epistemologically ambitious perspective.

At another level, he had a more general civic engagement: he wanted to "create awareness", which is, as we have seen, how he identified his ideal function in society. In this respect, Fuster is fully part of the tradition of the prototypical European intellectual, which includes Zola, Benda's clercs, Sartre and Camus, and has illustrious predecessors who can be traced back to humanism, the figure of Erasmus, who was torn between obedience to the power of Rome and freedom of thought. Authors such as Camus and Silone, whose works he introduced into the literature in Catalan, are the living embodiment of this resistance to the orthodoxies of the church or a political party struggling to change the world (Salvador 2006). For several years now, a great deal has been written about Fuster's views on these intellectual representatives; so, I shall do my best not to spend too much time on them here. I merely mention them because they have to do with the subject matter of this paper.

As a bridge - or a hinge or an interface - between knowledge and opinion, the intellectuals of the 20th century were the product of a particular period - they had a privileged position at the height of journalism - in which humanists and enlightened scholars had the technological means at their disposal to communicate with the general public, while the social and political conflicts of these tumultuous times required the intelligent minds to intervene. This brought about an expansion of the exoteric dimension of the intellectual communities in opposition to the esoteric dimension that forced them to close ranks in an attempt to protect their knowledge. With the passing of time, less and less was required of intellectuals and even Sartre's star waned among the ashes of May 1968. Some years before this was to happen, Fuster (1960) had spoken of the "death of the intellectual", who, as a social construction, was extremely dependent on context: that is to say, on the historical conditions of every historical period. In this respect, as in others, Fuster's gaze never forgot the radical historicity of sociocultural phenomena.

Indeed, the demise of the illustrious prototype of the socially involved thinker has had effects that have lasted through the decades to the present day. Some prophets of doom have rung the death knell for what they believed to be an old museum piece that was as venerable as it was useless. Others believe that it is the logical consequence of the historical and cultural changes that shifted from the printed word to television and then to cyberspace. It is true that the change in historical, technological and political circumstances has meant that the 
functions that intellectuals had are now being carried out by experts, pundits and opinion-makers, who have taken over their role. The living myth has lost some of its meaning and, in the 21 st century, is now a symbolic character that is "in the terminal, photogenic and telegenic phase" (Debray 2001).

Without a doubt, and as Said ironically pointed out, intellectuals today cannot aspire to be full-time Cassandras.

What is more, there are not too many centauric figures around, like Fuster, whose thinking is as cross-sectional and ambitious (Salvador 1994). But he did respond to the demands and the conditions of possibility of his time. He practised a noble pedagogy, along the same lines as the Enlightenment, which struggled to popularise reason (that is to say, to make it available to the general public). He uses the Socratic Method to converse with readers and to attempt to transmit the principles of the critical attitude. Nowadays, some lucid minds are calling for committed social education in opposition to "l'idéologie managériale" (Rastier 2013), as well as resistance to the mercantilism that is invading the educational systems, to the power of the cultural technocracies and to the inertia of the narrow disciplines of academic specialists. Despite being a determined defender of technological progress in medicine, economics and communications, Fuster does not succumb to the dehumanising temptations of liquid (post)modernity. In his opinion, progress in science cannot be extrapolated to the humanities in the sense that the achievements of humanist thought have no sell-by date because the discipline "has the ambiguity of becoming extinct and surviving at the same time" (Fuster 2011c: 103).

Behind all these motifs of engagement, there is one that sums them all up: engagement with himself, with his personal originality, which is a topic that seduced him from his very first publications, particularly in Les originalitats (The Originalities). Jacobo Muñoz (2004: 66) says the following about all the factors that make up his life project: "If you will allow me to use the philosophical term, Fuster's engagement was ontic in nature. That is to say, he was engaged with his constituent parts: a language, a history and a culture." Muñoz seems to me to hit the nail on the head. His engagement is ontic: that is to say, with aspects that are substantial ingredients of his personal identity such as the language, geography, history and culture of his people, his ethical and civic convictions, and, without any doubt, his close relationship with literature as a reader, a critic and a creator.

\section{Literary practice under examination}

According to reliable oral sources, one day, Fuster came across some lines by a young Valencian poet - he had always been receptive to local literary output - which spoke of establishing "a biological commitment to the word" and he made the comment that, biographically, he fully identified with the idea. Even since his beginnings as a poet, he undoubtedly had an intense and passionate relationship with literature. He penned various collections of poems, which combined verses full of irony with highly personal self-portraits. I shall not deal with Fuster's lyrical output here, but I do feel the need to note the fact and its importance, particularly because it is an example of his personal involvement with poetry, even though in his prose, he often spoke with contempt of poets and their loathings, as well as the neurasthenic origins of poetic inspiration. When valuing the Cartesianism of his mind or his intense concern for issues of literary sociology, it cannot be forgotten that biographically he was also a poet as well as a great reader of poetry.

As he was well aware, he had little natural ability for the narrative - although he did translate novels into Catalan, perhaps as a form of substitution - but he mastered the aphorism and the art of the essay, which was based on his personal diary and often ended up as journalistic column writing. Whatever the case may be, the essay, which is a polymorphic genre by nature, became his emblem as a writer, the great reserve of stem cells and the philosopher's stone of his writing. The agile style of the essayist and the method of internal deliberation impregnate the whole of his work, even the (para)academic studies - We, the Valencians; Poets, Moriscos and Priests; Heresies, Revolts and Sermons; Contemporary Catalan Literature - and the tourist guides with some literary pretensions (The Valencian Country springs to mind). The hundreds and hundreds of pages that he produced were this scholar of literature's very own laboratory. 
The first attempts to understand Fuster's conception of literature were the references made to his work as a critic or analyst of Catalan literature (Suïls 1995; Martí Monterde 2002; Sullà 2012). His critical work focussed on writers from the Middle Ages and the Renaissance, such as Ausiàs March, Tirant lo Blanc and Joan Timoneda, as well as more contemporary authors, such as his beloved Salvador Espriu and Josep Pla. He also played a decisive role in the emergence of Vicent Andrés Estellés as a major figure in Valencian poetry by writing the introduction to his complete works in 1972. Fuster shrewdly interpreted the meaning of works and their aesthetic sense; he provided historical context, he freely gave his opinion as well as his subjective appraisal as a reader. In one of his works, Contemporary Catalan Literature (which can inevitably be used to some extent as a textbook), he demands the freedom to practise subjective judgement. In the prologue to the first edition in 1971, he states his case in the following terms:

So not "text book" or "repertory". Neither am I arrogant enough to suggest a "critical history". The noun "criticism" and its cognates have always put me off, particularly the professional or professorial meanings that they usually convey. I do not regard myself as a "critic", and I have no desire to be one. The notes that I have accumulated are, essentially, notes made by a consumer: they are the result of my having read an enormous amount of paper, with my own reasons for doing so and in my conditions. (Fuster 1978: 6)

The main value of this procedure lies precisely in "having read an enormous amount of paper", of having re-read it - which is the only serious way to read - and of having regurgitated it in an exercise of self-examination.

With no pretence of scientific objectivity - a mania that other critics attempt to legitimate with resources ranging from crude erudition to quantitative stylistics or abstruse terminology - Fuster cheekily exercises his right to enter into combat with the books, a sort of test of inter-subjectivity in which the "I" of the critic, of the reflexive and proactive reader, confronts the texts. After all, this is how essayists behave: they examine how they have digested external realities, one of which is the universe of literature. Because literature, like the other arts, generates realities, even though these realities are little more than constructions of imaginary worlds: as the aphorism says "When the painter paints, the world grows." (Fuster 1992: 43).

But despite his provocative rhetoric, Fuster is perfectly aware that literary criticism - journalism, academic articles and even the textbooks that set the canons - is a key element in the machinery that sets the products of writing circulating in society. He even regards this secondary role of the literary scene as one of its essential vocations: "Somebody once observed that no statue has ever been made in honour of a critic. This may be one reason why critics reaffirm their sense of vocation" (Fuster 1992: 69). One of the most common clichés levelled at critics, who are often perceived as a dispensable burden, is that "the removal of intermediaries would, so it seems, lead to direct democracy, with no barriers between writers and readers" (Sullà 2012: 190). In the text in which he explores Fuster's critical work, Sullà himself argues convincingly against this prejudice. Reformulating the aphorism cited above, we could even go so far as to say that when critics do their job well, literature grows: all forms of interpretation create meaning.

It should not be forgotten, however, that Fuster's intervention in the public domain, beginning with his own field, is based on an internal debate that culminates in his presenting the results of his self-deliberation to the reading public. But on some occasions, the debate is not just internal; it involves some other agent provocateur, an adversary who generates interaction. For Fuster, who was no stranger to the art of controversy, a sharp opponent was an extremely useful stimulus, someone who could help clarify ideas. And, what is more, creating controversy, in his opinion, is also a way of teaching the reading public. This may be true of all controversies on all issues, particularly on literary ones. One example is the really quite bitter dispute he had with Joan Ferraté on Espriu's poetry for some months in 1968 and 1969. Fuster defended his opinions as a freelancer in the world of culture - an attitude he was to assume on other occasions, too - against an adversary who he associated with the world of academia and the worst habits of the teaching establishment. 


\section{Genres}

Fuster's opinions on poetry can be found throughout his work, in journalistic articles, in aphorisms or in the pages of his Diari (Day-to-Day Works). He is often rather offhand in his comments. Nevertheless, disregarding his allusions to the vanity of poets, their pet hates and the therapeutic function of writing verse, he deals with the topic of poetry on various occasions over the years. In some texts, particularly those that were written in the 1950s, such as Causar-se d'esperar, poetry is portrayed as "the artistic extreme of literature" (Fuster 1965: 129), although there are also references to its usefulness for the reader, for literary consumption. Fuster was much more explicit in another text from the same period, Tres notes marginals (Three Notes in the Margin), which came from his Day-to-Day Works, was a part of Figures of Time and was included as an independent book in the volume Assaig (Essay) of his complete works (Fuster 2011a). Starting from Maragall's definition of poetry as "language in a thermal state", he makes various interesting remarks. For example: "Interjecting the common language would indeed be the poetic way of expression, that is, poetry itself; this would be the "thermal state" to which I have referred. The interjection is the most delicate and elastic instant in language: it is the word in its nascent state" (2011a: 172). It is not, however, a perspective of the ideal style: rather, other parts of the same text focus on the clear functional aspects of poetry: "Rhyme and all the sound plays to which words lend themselves help poetry to save language from expressive inertia" (2011a: 173). There is also a lack of trust in the inspired spontaneity of poetic writing: "We do not know all the cunning that is concealed by works written under the sign of spontaneity" (ibid).

Even more explicit is his approach to the relationship between poetic diction and the conventional uses of language: "To communicate the reality that he sees or feels, the poet has at his disposal only a few words for tribal, pragmatic use" (Fuster 2011a: 174). The poetic word must acquire the status of living word through the whole set of discourses used in practical communication, from which it must necessarily drink, but adding something else so that it can, by way of catachresis, name that which seems unnameable:

The words of a poem are alive. That is to say, they have a significance in a system of relations that are unceasingly unpredictable and indeterminate. They go beyond dry convention, beyond the immobility they have in discourse and in the vocabulary of teaching. As they come into subjugating contact with one another, their semantic and phonic potential is inexhaustible. The language of the poet comes, as it were, to the boil: it is constantly subject to a violent, internal tension, because of an effort that we could refer to as catachrestic, or as the expression of the inexpressible. The poet speaks - or sings - so that others may understand him; but precisely for this reason, for them to understand him, for them to understand something that is so difficult to convey as the secret melody of dreams, words need to be given a parallel ring or meaning. (Fuster 2011a: 172)

Logically, this conception of the expressivity of the poetic word cannot be reconciled with the ways in which poetry is used as mere political propaganda and doctrinal didacticism, something that would be a socio-historical contradiction:

Communism, then, has been obliged to seek refuge in art pompier, which does not have the shortcomings of form or content. Art pompier is now mandatory. This is another paradox: proletarian art - of the successful proletariat - is horribly similar to the art that was in fashion in Europe before Impressionism, at the height of the 19th century (that is, the most bourgeois art known to mankind). (Fuster 2011a: 160)

Although this conception of poetry is predominant in Fuster's work in the 1950s, when social poetry took off during the next decade, he qualified his words a little more, as we can see from the response he gave in 1962 to the survey carried out by Serra d'Or. Such drastic sentences against Communist art are conspicuous by their absence, e.g., and he insists on rejecting hermetic poetry (of "highly restrictive and obsessive circles"), which is one of Fuster's constant themes. To sum up, he accepts that it is legitimate to make room for the expression of the individual's private domain but, at the same time, there should be a clear commitment to the aesthetic autonomy of poetry: "Love? As poetry, quality; as its 'social value', everything else" (Fuster 2011b: 53). The notion of engagement, on the other hand, broadened its scope to include Espriu's "civil" poetry and the poetry of 
the Catalan Renaixença, which remained faithful to the collective circumstances of the times. And finally, in response to the eternal temptation to "dumb down" literature so that it could reach the masses, Fuster adopts the reasonable attitude of "dumbing up" (not the opposite). It should not be the poet who reduces his linguistic and aesthetic quality: "The masses have to draw nearer to him: they must be able to read poetry. I insist: there are basic problems of education, of public learning" (2011b: 53).

The novel has a different problem because it is a genre that deals with "things"; it is a window that opens onto the life of society. This is what Fuster was thinking of when, at the beginning of the 1970s, he denounced the "extraordinary lack" of the narrative novel in the Valencian Country. Generally speaking, he conceives fictional narrative as mimesis and the most suitable product for activating the business of publishing because of its ability to attract readers. If poetry is not sung as, e.g., it was in the nova cançó, which was of great interest to Fuster (particularly the figure of Raimon), it is highly likely that it will appeal only to a minority. When theatre does not resign itself to being merely text read out loud, it has a range of other limitations: long runs of lavish productions are rarely viable because of financial problems and a lack of cultural policy. The novel, however, is a fundamental ingredient in a literature such as the Catalan one. More generally, for Fuster, novels are particularly valuable because of the characters and the plots they portray - The Three Musketeers or The Wandering Jew, let's say - and not because of any formal experimentation or "exercises in verbal digitation": "The novel has been and is the telling of an unprecedented 'experience'. The unknown is returned to us in intriguing formulas" (Fuster 2010: 100). After all, the tale is a knowledge strategy that complements the strategy of the explanatory or discursive discourse of the science, the philosophy or the essay. From his point of view, reading novels helps one to understand others even though the events are fictional and it is "a communicative resource that is not used by historians, sociologists, economists, biologists..." (ibid). We should add that psychologists have taken full advantage.

Nevertheless, as in all genres, this understanding of others, of the real world, which is revealed and described in the narrative fiction, is also a way to understand the author who is writing. As the aphorism goes, "Mauriac says that the aim of literary novels is 'to understand man'. The man who writes, I would say." Of course, according to the school of Sartrean thought, the man always reveals himself when he writes, or when he chooses a woman or a tie. This idea, carried to the extreme, can be generalised to all sorts of writing, and particularly to the essay, in which the self is projected in the opinions of the essayist parallel to - but different from - what takes place in lyric poetry (one must limit oneself to the interests of the public agenda). Because by creating the genre, Montaigne made it possible to brazenly write "I" outside the confines of lyric poetry: "His Essais can be read as an autobiography without anecdotes, as a reflection on the world and its vicissitudes from the viewpoint of a perplexed 'self'" (Fuster 2010: 259). The idea of an intellectual autobiography with no private anecdotes is, of course, a feature of Fuster's essays, and even his literary criticism, as Martí Monterde (2002: 74) points out: "Like Oscar Wilde, Fuster is convinced that criticism is one of the most civilized forms of autobiography, and this commitment to the constitution of individuality is its maximum guarantee." Fuster goes even further: "To some extent, all painting is self portrait" (Fuster 1992: 142).

It is writing about the self but without the ingredient of private confession. The confessional element comes to the fore only very occasionally. One example is an article published in 1983 in Serra d'Or as part of the series "Passar el dia, empènyer l'any", significantly entitled "Nota autobiogràfica" (Fuster 2011b: 518-520), and which is a reflection on his own old age and the relationship between his first lyric poem and the existentialist climate of the age. Generally speaking, however, these private allusions are mere anecdotes typical of the, let's say, feature writer who has established a certain familiarity with his readers and decides to use personal references not necessarily true - to illustrate an idea with an effet de reel. These strictly personal anecdotes often have a strong element of irony. Fuster is a master of the procedures for involving the reader using ironic nudges and winks. But let us not deceive ourselves; this rhetorical ability has very little to do with the confessions so characteristic of the personal diary or lyrical exhalation. Nevertheless, even though he does not adopt a familiar tone, he requires the reader to get involved because, otherwise, the essayist cannot put his internal deliberations on display. 
Josep Iborra, one of the critics who has most analysed Fuster's thinking, has stressed that Fuster's diary is an instrument not of confession but of research, the intention of which is more prospective than introspective. The essayist explores his experience of the realities he observes or has been involved in by simulating a conversation with the reader, and he does so with the ultimate aim of influencing society: "In fact, after all, the perspective that inspires Fuster's work is precisely to influence the civic and cultural dynamics of his society" (Iborra 2014: 246).

He fulfils this desire to influence society by publishing classical essays in book form, writing series of essays in the newspapers and formulating his aphorisms, his "capsules of doctrine": those brief messages that, as he himself confessed, he copied from the Jesuit almanacs of his childhood. This urge to instruct, however, does not follow the path of the simplified announcements of the preacher or the seller of papal bulls; instead, it relies on the reader's reflexive collaboration. We could say that Fuster's writing is more enigmatic than instructional because he generally uses the element of surprise, expressive brilliance and a certain difficulty usually associated with conceptisme, which, when overcome, gives the reader the satisfaction of a test passed.

\section{Historicity, reading and literary market}

Returning to Fuster's "theory of literature" - which, by the way, can also be seen in his aphoristic microtexts his conception of both Catalan and universal literature aims to be comprehensive and account for the complexity of literary practice in all areas and uses. In the first place, he is aware of the cognitive virtuality of literature as a source of historical, psychological, sociological and even philosophical knowledge; or, more immediately, as a means of self-knowledge. Also, even though he is not an ivory-tower aesthete, he is extremely sensitive to the artistic values of the literary word. And finally, without being a dialectical materialist - he says that he does not understand the complexities of the Marxist doctrine - he does say that he is staunchly in favour of historical materialism, which - in his opinion - includes what we could refer to as biological materialism: human bodies and their physiologies, in conjunction with social structures and power relations.

The very complexity of Fuster's thought is always attentive to the historicity of any human product, including literature. For him, the classics are not so much a timeless canon but a sort of dynamic archive that are successively read in the context of each age. The language used by Ausiàs March, e.g., ages and can be problematical for readers in less than a century. But, 500 years later, it can recover an unsuspected vitality and become a stimulus for poets of the 20th century (Vicent Andrés Estellés, for instance). The classics can also become outdated and then recover their former glory in another historical context. Literature unavoidably interacts with history by reshaping the contexts of reception, which are extremely mobile, and can determine when some products become outdated: "When Stendhal predicted that people would begin to understand his work in 1890 - a few years more or less - he could have added that by 1990 they would have stopped understanding it." (Fuster 1992: 75). In this regard, his reflections on reading undoubtedly contain a theory of reception, which deals not only with the process of individual reading/interpretation but also with the changes in socio-historical reception horizons.

Something similar can be said about the emergence of the figure of the intellectual, which Fuster lucidly regards as being a part of the process of evolution of the historical context: that is to say, from the humanist and enlightened predecessors - Erasmus and Voltaire - to Zola's famous "J'accuse" and Sartre in the post-war period, full of the contradictions of international communism. This figure from the petit bourgeoisie, or of no particular class, would then go into decline (Fuster 2011a: 169-170) which, as we have seen earlier, Fuster had already predicted in 1960. Indeed, if the intellectual is a socio-historical construction, his reign takes a downturn with the radical mutations in the technology of communications and, on a deeper level, with the changes in a contemporary society characterised by individualism and an ignorance of social criticism, and which makes do with a media expert, an esoteric guru or, quite simply, banal infotainment. Edward Said described the sense of relief that some rather mediocre cultural sectors felt when the great masters had disappeared or been declared 
obsolete:

At the beginning of the 1980s, when most of the maitres penseurs had disappeared, their absence was accompanied by a certain relief and no little rejoicing, as if the newly found superficiality gave many people the chance to have a voice for the first time since Zola. (Said 2006: 148)

Going back to the issue of the social reception of literature, the pragmatic conception that gives such a prominent role to contexts is particularly important in the global perception of Catalan literature, and especially - this is Fuster's main concern - of its conditions of possibility (Iborra 2014: 248-249). From a perspective of literary sociology, which a historical materialist would do well to bear in mind, these conditions of possibility depend on a wide range of output that is not restricted to the plethora of genres that socially are in a minorityparadigmatically poetry - but which covers all fictional narrative, including the least prestigious genres such as crime or romantic novels, theatre (including the scripts of television series), songs, comics and translation, which is regarded as a valuable way of incorporating texts into the abundance of literature in Catalan. After all, the aim is for the store to have such a wide range of assorted texts that it can attract a loyal clientele and neutralise the temptations offered by the competition, particularly the competition of the superimposed Spanish literature. Literary market? But of course! For Fuster, the "bookshop business" needs to be promoted without any sort of metaphysical shame because, otherwise, Catalan literature is simply inviable.

Finally, when weighing up the need for this literary circuit, there is one aspect that may seem paradoxical. I am referring to Fuster's insistence on the need to have professional writers on the circuit. In his opinion, under no circumstances should they be part-time, Sunday-afternoon amateur enthusiasts. Apparently, this is in direct contrast to the attitudes of some authors, like Said, about the professionalisation of intellectuals. However, if we take a close look at Said's words (2007: 93), we shall see that the term is ambiguous and that it may involve an element of trivialisation, commercialisation or bureaucratisation:

By professionalism I understand that, as an intellectual, you conceive your work as something you do to earn your living, from 9 in the morning to 5 in the afternoon, with one eye on the clock and the other focused on what is thought should be appropriate professional practice: you should not cause any trouble and you should not transgress accepted paradigms and limits. In this way, you make yourself sellable in the marketplace and, above all else, presentable (that is to say, not controversial, apolitical and 'objective'.

Fuster and Said are clearly speaking about different things. In the first place, one of them speaks of writers in general and the other of intellectuals. In fact, although Fuster himself belongs to the two categories - as does Sartre, who often preferred the term "writer" to refer to himself - the writers for whom Fuster demands professionalisation are not necessarily the "intellectuals" who from a pre-eminent position in the Republic of the Arts intervene in social affairs, but all those who, in the context of a minoritised language, are forced to produce literary texts as limited amateurs.

Fuster was committed to the idea of "manufacturing" the Catalan literature of his age and, as a result, he demanded the conditions required for it to develop: authors - and translators - who can live from their writing; a wide range of themes and genres, as in any normalised literature; critics who detect quality and guide the general public through the most suitable media; publishers who organise the sale of the products; educators of taste who have teaching platforms available to them; and, finally, enough readers so that the circuit can remain in operation and to make it grow.

Then, using a solid critical mass, the quality work must be discerned from the rest because, of course, not all literary output is "good" literature. Nevertheless, this does not mean that some genres can be rejected without a second thought because they all have a role to play in the quest for excellence: "The most insignificant and repulsive literary genres can be expressed quite brilliantly. This is what Shakespeare did with melodrama; Dostoyevsky with the feuilleton; Hegel with philosophy; Aristophanes with old comedy" (Fuster 1992: 63). Despite his ironic use of hyperboles, which liven up this aphorism, we cannot deny that there is an undeniable basis of truth. 


\section{Coda: the multiple engagement}

Fuster's engagement with culture, then, is not limited to his selecting a particular sociopolitical option; his attitude is complex, full of nuances and by no means free of paradoxes. There are many different threads: engagement with literature in general and with Catalan literature in particular; with his language as a sign of national identity; with the problems of his society; with the fostering of the critical spirit of his fellow citizens. And above all else, he aims to remain faithful to his own self-examination. Iborra attempts to define this complexity with the following, highly illustrative words:

Saying that Fuster is engaged, comparing his influence with that of the engaged intellectual, does not fully define his perspective. Because he is not interested in merely siding with certain ethical, social and political options, but of contributing with his writing, with his words and with his action to awakening energies and channeling them constructively and creatively. (Iborra 2014: 246)

Acknowledgements. Project FFI2013-40934-R: "Retórica constructivista: discursos de la identidad".

\section{References}

Debray, R.: "Muerte de un centenario: el intelectual", El País (3-6-2001), 2001.

Fuster, J.: "La muerte del intelectual", La Caña Gris 1 (1960): 3-5.

Fuster, J.: Causar-se d'esperar. Barcelona: A. C., 1985.

Fuster, J.: Literatura catalana contemporània. Barcelona: Curial, (1978 [1971]).

Fuster, J.: Consells, proverbis i insolències. Barcelona: Edicions 62, 1992.

Fuster, J.: Correspondència, 6. València: Tres i Quatre, 2003.

Fuster, J.: Discordances. Alzira: Bromera, 2010.

Fuster, J.: Obra completa. Assaig, I, Barcelona: Edicions 62, 2011a.

Fuster, J.: Obra completa. Assaig, II, Barcelona: Edicions 62, 2011 b.

Fuster, J.: Més discordances. Alzira: Bromera, 2011c.

Iborra, J.: Fuster, una declinación personal. València: PUV, 2014.

Martí Monterde, A.: "Joan Fuster i la idea de crítica literària", L’Espill 10: 68-79, 2002.

Muñoz, J.: "Joan Fuster, entre el compromiso y el distanciamiento", Quaderns e filosofia i ciència 34 (2004): $61-66$.

Nicolàs, M.: "El vol de l'òliba. A propòsit de la imatge intel·lectual de Fuster", L'Espill 10 (2002): 144-153.

Penalba, N.: "Joan Fuster: Entre Sartre i Camus, Erasme". In: A. Martí Monterde \& B. Padró (eds.), Qui acusa? Figures de l'intel-lectual europeu. Barcelona: Universitat de Barcelona, 2015, p. 263-272.

Pérez i Grau, D.: El País Valenciano de Joan Fuster i la descripció del territori: producció textual, traducció i recontextualització. TD/Universitat Jaume I, 2016.

Rastier, F.: Apprendre pour transmettre. L'éducation contre l'idéologie managériale. París: PUF. 
Said, E. W.: Humanismo y crítica democrática. La responsabilidad pública de escritores e intelectuales. Barcelona: Debate [1st edition in English: 2004], 2006.

Said, E. W.: Representaciones del intelectual. Barcelona: Debate [1st edition in English: 1994].

Salvador, V.: Fuster o l'estratègia del centaure. València: Bullent, 2007.

Salvador, V.: "L'escriptor, de llengua en llengua: Joan Fuster i les traduccions", Caplletra 40: 211-234, 2006.

Suïls, J.: "La crítica literària de Joan Fuster",. In: N. Perpinyà (ed.), Lectures al quadrat. Lleida: Pagès Editors, 1995, p. 185-243.

Sullà, E.: "Una defensa de la crítica literària". In A. Martí Monterde \& T. Rosell (eds.), Joan Fuster: figura de temps. Barcelona: Universitat de Barcelona/Institució de les Lletres Catalanes, 2012, p. 166-192 